Jejak Vol 11 (2) (2018): 338-357, DOI: https://doi.org/10.15294/jejak.v11i2.16056

\title{
JEJAK
}

Journal of Economics and Policy

http://journal.unnes.ac.id/nju/index.php/jejak

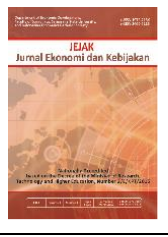

\section{Monetary Policy, Foreign Interest Rate impact on Indonesian Bank Credit}

\author{
Taufiq Carnegie Dawood ${ }^{\bowtie}$ \\ Faculty of Economics and Business, Syiah Kuala University, Banda Aceh \\ Permalink/DOI: https://doi.org/10.15294/jejak.v11i2.16056 \\ Received: April 2018; Accepted: July 2018; Published: September 2018
}

\begin{abstract}
This study adds to the economic knowledge by presenting proof based on data for Indonesia, on the consequence to credit provided by domestic banks, due to changes of monetary policy and foreign rates of interest. The subject matter is important for Indonesia because about 88 percent of its overall financing to the private sector in Indonesia are provided by domestic banks through credit channels. Consequently fluctuations of bank credit have significant impact on Indonesia's financial system's stability. Applying the Structural VAR method, the current study found that credit channeled by domestic banks in Indonesia are influenced by both rates of interest from abroad and the policy stance of Bank Indonesia. In addition it is found that foreign rates of interest effects bank credit negatively, but turns positive after 12 months. While a monetary contractionary monetary stance by Bank Indonesia decreases the quantity of credit provided by banks. These results underscores the limitation of monetary policy in managing bank credit growth. This results also underlines the need of Bank Indonesia to take into account the impact of foreign interest rates in conducting macroprudential policies in overseeing credit growth to promote financial stability in Indonesia.
\end{abstract}

Key words : foreign interest rate; bank credit; monetary policy, SVAR

How to Cite: Dawood, T. (2018). Monetary Policy, Foreign Interest Rate impact on Indonesian Bank Credit. JEJAK: Jurnal Ekonomi dan Kebijakan, 11(2), 338 - 357. doi:https://doi.org/10.15294/jejak.v11i2.16056

\footnotetext{
Corresponding author :

Address: Faculty of Economics and Business, Syiah Kuala

p-ISSN 1979-715X

University, Banda Aceh, Indonesia

e-ISSN 2460-5123

E-mail: taufiq.dawood@unsyiah.ac.id
} 


\section{INTRODUCTION}

Bank Indonesia is the custodian of financial stability in Indonesia. This role is stipulated as one of the mission of the central bank of The Republic of Indonesia. As a developing country, financial intermediation is an important factor for the development of the Indonesian economy.

Many scholars cited that the global financial crisis of 2008 has shown the key role of financial intermediation in the stability of an economy, and in policy making, in particular monetary policy. Reinhart and Rogoff (2008) argued that the newly set up and unregulated or lightly regulated financial entities such as the Sub Prime Mortgage Market in the United States before the wake of the 2008 global crises, had increased vulnerability of the United States's financial system and intermediation. This outcome then resulted into the global financial crises of 2008. Using a UK Bank as a case, Shin (2009) argued that vulnerability in financial intermediation system stemming from institutional investors' reliance on short term financing has resulted it being prone to negative external financial shocks. In turn, the Mortgage back securities debacle in The United States has resulted in the wake of deleveraging of the UK and global credit markets. This in turn disturbed domestic and global financial intermediation and resulted in the global financial crisis of 2008. Claessens et al. (2010) argued that new and more sophisticated financial intermediaries and instruments and household debts coupled with flaws with policy frameworks and weak supervision of the state of health of the intermediation system, were at the heart of the global financial crises. In addition this paper argued that although monetary policy and micro-prudential policies are necessary but they are not sufficient in safeguarding the economy from shocks which may have detrimental effects to the macroeconomic condition of the country. Furthermore Blanchard, Dell'Ariccia and Mauro (2010) argued that financial intermediation regulation cannot be left outside the core macroeconomic policy framework because a stalled financial intermediary system have detrimental effects on the real economy as shown from the global financial crisis of 2008. Adrian and Shin (2010) argued that financial intermediaries is the engine of the financial cycle. The financial cycle in turn is at the heart of the risk taking channel of monetary policy transmission mechanism. And Rey (2016) argued that the 2008 global financial crisis has underlined the importance of financial frictions on the monetary policy transmission mechanism (in particular the international transmission mechanism of monetary policy), and financial stability. This paper also underlines the importance of financial stability for macroeconomic soundness.

In Indonesia, like in many developing nations, financial intermediation, especially the banking sector, plays a more prominent role in the provision of financing than other financial sectors such as the capital market or the bonds market. Based on The Bank for International Settlement's data, a proportion of 88 percent of financing to the private nonfinancial sector was provided by the banking sector in Indonesia in the second quarter of 2017. This proportion of bank financing in Indonesia is above the average for developing countries, which around 79 percent in the second quarter of 2017. Furthermore, the percentage of financing channelled by the banking sector in Indonesia is far above that of the average for developed countries which is about 55 percent. As a note, from the data 
of The Bank for International Settlements it is also shown that the percentage of financing channelled through the banking sector is much higher in developing countries (79 percent) than in developed countries (55 percent. (See tables $\mathrm{A}_{1}$ and $\mathrm{A}_{2}$ in the Appendix). This fact underscores the importance of bank credits for developing countries in general, and for a developing country such as Indonesia in particular.

Discussions on the effect of monetary policy on bank credit has been studied extensively in the literature. It is termed as the bank credit channel of monetary policy transmission mechanism proposed by Bernanke and Blinder (1992). This paper empirically studied the influence of monetary policy on bank credit for the United States. The bank credit channel of monetary policy transmission mechanism has been extended by Matousek and Sarantis (2009), De Mello and Pisu (2010), Disyatat (2011), Altunbas, Gambacorta and MarquesIbanez (2010), Jiménez and Ongena (2012), Vera (2012), Jiménez et.al. (2014), Bruno and Shin (2015), Cúrdia and Woodford (2016)). This set of literature concludes that a rise of the monetary policy rate resulted in a fall of bank credit, but with a lag.

However discussions on the effect of foreign interest rates changes on domestic bank credit in the literature is still very limited. One study which focus on the relationship of foreign interest rate and exchange rate on domestic bank credit is Zanforlin (2011). This paper studied the relationship between cross country interest rates differentials (in this paper it is also termed as foreign funding cost), real exchange rate and domestic bank credit to the private sector by employing a panel of annual data of 91 countries from the span of
1970 to 2001. This study concluded that there is a negative relationship between foreign funding cost and bank credit, while the real exchange rate is positively related with domestic bank credit.

Similar to the relation between foreign interest rates and exchange rates with domestic bank credit, discussions of the relationship between other macroeconomic variables with domestic bank credit is limited. Imran and Nishat (2013) which study bank credit determinants in Pakistan, found that there are significant relationship between economic growth, exchange rates and bank credit, but there is an insignificant relationship between inflation and bank credit. Guerra (2017) which studies economic growth and bank credit in Mexico, found that growth of GDP has positive effect and granger-causes bank credit growth.

Given the thin literature of the effect of foreign interest rates on domestic bank credits, there is yet to be a study which analyse the effect of both monetary policy and foreign interest rates and other macroeconomic variables on domestic bank credit. Such study would provide valuable information for policy making to help achieve stability in its financial sector of a developing economy opened to foreign capital flows such as Indonesia.

In relation to the significant role of bank credit to the financing landscape of Indonesia, this following section presents data of bank credit together with monetary policy, foreign interest rates and other macroeconomic variables. In this study, monetary policy stance is measured by the dynamics of the time series of monetary policy rate of Bank Indonesia. The foreign interest rate used in this study is proxy by the time series data of The Federal Funds 
Rate of The Federal Reserve Bank of The United States.

Monetary policy rates can affect bank credit in Indonesia. This can be seen from figure 1 below. Figure 1 shows the time series data for monetary policy rate used by Bank Indonesia with domestic bank credit allocated to the domestic private nonfinancial sector in Indonesia channelled by domestic banks. The time series for domestic bank credit and the monetary policy rate for Indonesia are monthly data which spans from January 1999 to July 2017. As shown in the figure 1, a rise in monetary policy rates in Indonesia due to a monetary contraction by Bank Indonesia tends to decrease domestic bank credit. There are episodes in the data that show that a rise in the policy rate results in a fall in bank credit. From figure 1 it can be seen that a sharp rise in Bank Indonesia policy rate in January 1999, supposedly due to the Asian financial crises, results is a sharp fall of domestic bank credit allocated to the domestic private non-financial sector. Similar episodes can be seen in January 2002, where there was a jump in the Bank Indonesia's policy rate rose to almost 18 percent. This resulted in a sharp fall in the growth of domestic bank credit allocated to the domestic private non-financial sector to slightly above 71 percent. Similarly in February 2006 there was a spike in the policy rate. The spike in the Bank Indonesia policy rates around 15 percent resulted in a fall in the growth of domestic bank credit allocated to the domestic private non-financial sector by around 3,71 percent. Similarly, possibly due to the wake of the global crises spurred by the mortgage backed securities debacle in the United States, Bank Indonesia raised its policy rate to 11.24 percent. This resulted in a decrease in the growth of domestic bank credit allocated to the domestic private nonfinancial sector by 3.2. Percent.

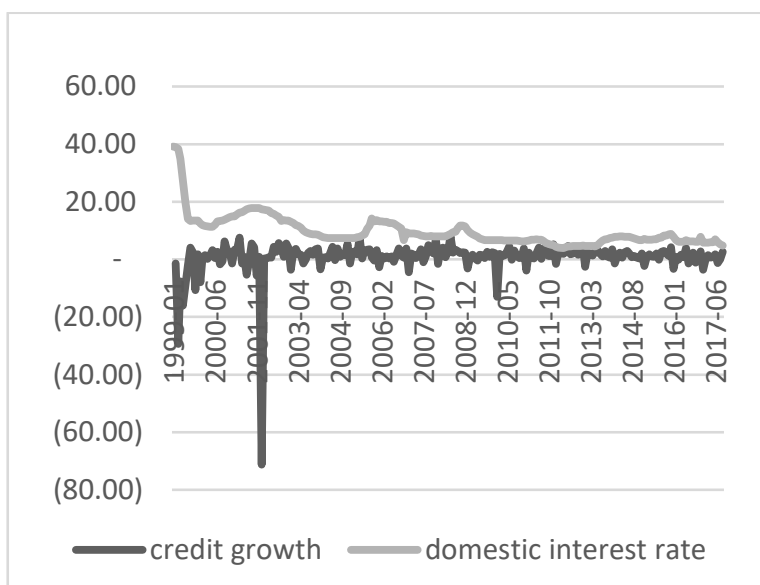

Figure.1. Policy rate and bank creditSource: Bank Indonesia (processed)

On the other hand, a fall in policy rates due to a monetary expansion by the Indonesian central bank tends to increase bank credit in Indonesia. Figure 1 above shows that from January 2001, Bank Indonesia policy interest rates fell dramatically from 17.57 percent in August 2001 to become 7.37 percent in September 2005. This significant reduction of Bank Indonesia's monetary policy rates resulted in a gradual rise of domestic bank credit allocated to the domestic private non-financial sector from around less than 0.5 percent to become around 5.4 percent. Similarly Bank Indonesia reduced its monetary policy interest rates from 12.75 percent in January 2006 to become 7.93 percent in March 2008. This gradual reduction of bank Indonesia monetary policy rate has resulted in a gradual rise of domestic bank credit allocated to the domestic private nonfinancial sector from around.

Analysis on the relationship between the quantity of bank credit and monetary policy has been discussed in length in the literature. A pioneering paper on the effect of monetary policy on bank credit is (Bernanke \& Blinder, 1992). This paper empirically studied the 
influence of monetary policy on bank credit for the United States, concluded that a rise on the Federal funds rate resulted in a fall of bank credit, but with a lag. An extension of this work was conducted by Vera (2012), by including more recent data points. Vera (2012) obtained similar conclusions as in the aforementioned paper but this paper showed that the impact of monetary policy on bank credit in the US has fallen over the period. There are further extensions of the relationship between monetary policy and bank credit. Altunbas, Gambacorta and MarquesIbanez (2010) found evidence monetary policy affects the amount of credit in European banks. In addition this paper found that the potency of monetary policy bank credit depends on the level of risk of banks. This paper found that banks with lower expected default frequency tend to be less responsive to changes of the monetary stances of the central bank compared to banks which have higher level of risks. In addition this paper found that the potency of monetary policy on bank credit depends on the level of financial innovations. Larger financial innovations results in weaker influence of monetary policy on bank credit. In similar light, Jiménez et al. (2012) studied the effect of changes of monetary policy stances on bank credit in the Spanish banking system. This paper found that a monetary contraction resulted in a reduction in bank credits in Spain. In addition this paper found that the responsiveness of the bank credit due to changes of the monetary policy stance depends on the banks' capital and liquidity. Banks with lower level of liquidity and capital tend to be more responsive to changes in monetary policy stances than banks with higher capital and liquidity. In addition Jiménez et al., (2014) also found that with a monetary expansion, banks in Spain tend to increase their credit supply, but in they also increase the level of risk of their credit portfolio by granting bank credit to more risky borrowers. Cúrdia and Woodford (2016), by construction an extended version of the New-Keynesian model, found that a monetary contraction results in a reduction of bank credit through the channel of increased credit spread.

Indonesia is an open economy which has an open capital account system, which enables foreign funds to flow in and out relatively freely to and from Indonesia. Due to this system, foreign interest rates may influence economic conditions in Indonesia. This serves as a challenge for monetary policy making for Bank Indonesia, and also for monetary authorities of other developing economies as argued by the following scholars. Di Giovanni and Shambaugh (2008) found that high foreign interest rates results in contraction of the real GDP of the domestic economy. This contractionary effect of foreign interest rates on real GDP only exist in countries with a fixed exchange rate regime. This serves as a challenge for monetary policy making because maintaining the real output gap is one of the objective of monetary policy. Aizenman and Glick (2009) found that sterilization was widely conducted in Asia and Latin America due to worries of hiking inflationary impact of inflows of foreign reserves. Mishkin (2009) argued that globalization did not lead to the decline of the impact of monetary policy stance changes on inflation and domestic output gaps. Furthermore this paper found that foreign monetary policy (through foreign output gap) did not have an important impact on domestic inflation and thus did don't have the role of demising the potency of domestic monetary policy in fighting inflation. In addition this paper 
argued that domestic monetary policy have sufficient power in controlling domestic interest rate, which is used as the main instrument for controlling domestic inflation and output gap. Bruno and Shin, (2015) found that a contraction of the monetary policy stance of the United States results in a decrease in a decrease of international banks' cross-country capital flows. This paper argued that this factor partially explains the flow of capital from developed countries to developing countries in the 1990-s. In addition Ghosh, Ostry and Chamon (2016) that in a economy affected by globalization, the optimal policy response of a developing country in their attempt to tame inflation and weaken the negative affect of an exchange rate disequilibrium is to use a combination of monetary policy and exchange rate interventions.

The open capital account system which implies that capital can freely move to and from Indonesia may have an impact on domestic bank credit provision in the country. This condition is indicated in the chart below. In the figure below shows some indication that there is a tendency for bank credit to decrease as a result of an increase in foreign rates of interest. From figure 2 it is shown that when foreign interest rates increased from 5.07 percent in August 1999 to become 13.56 percent in October 1999, the rate of growth of domestic bank credit allocated to the domestic private nonfinancial sector fell by 10.7 percent. Similarly, although in a milder magnitude, in August 2000, the Federal Funds Rate increased to 6.5 percent. This development resulted in a decrease of domestic bank credit allocated to the domestic private non-financial sector in Indonesia to fall by 1.6 percent. In addition, when the foreign interest rates decreased from 2.98 percent in February 2008 to become 2 percent in June 2008, the growth rate of domestic bank credit allocated to the domestic private non-financial sector in Indonesia increased by 8.1 percent.

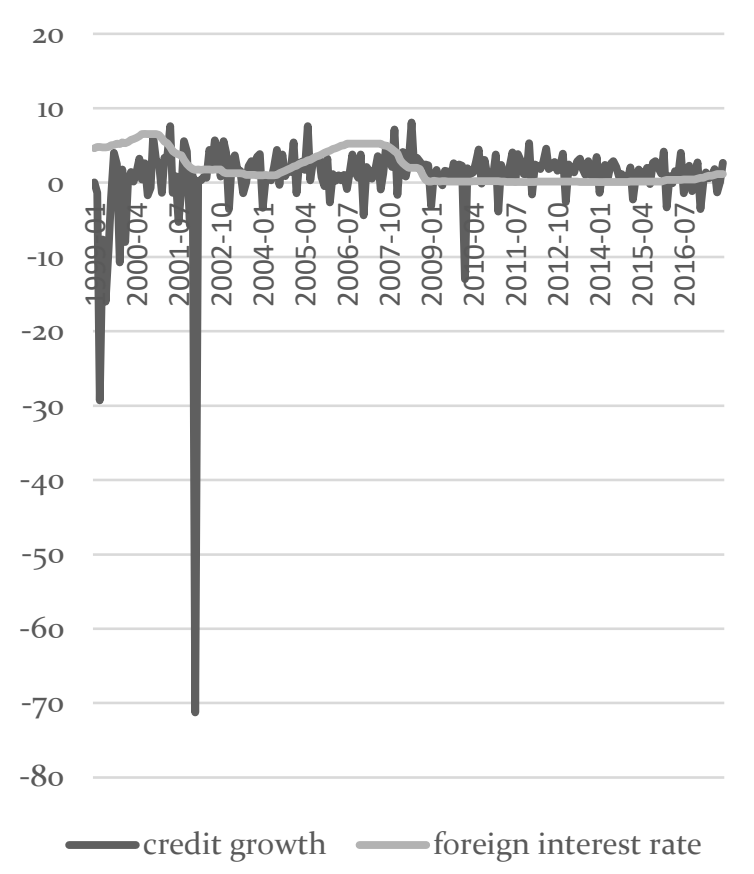

Figure.2. foreign interest rate and bank credit Source: Bank Indonesia (processed)

However there is also a tendency that foreign interest rates, in this case the federal Funds rate, move in the same direction as the growth of domestic bank credit allocated to the domestic private non-financial sector in Indonesia. Figure 2 shows that when foreign interest rates decreased from 2.49 percent in October 2001 to become 2.09 percent in November 2001, the growth of domestic bank credit allocated to the domestic private non-financial sector in Indonesia fell by 5.7 percent. Similarly when, the Federal Funds Rate decreased further 1.73 percent, the growth rate of domestic bank credit allocated to the domestic private nonfinancial sector in Indonesia fell by 71.2 percent. In the opposite direction, the Federal Funds Rate increased from 4.99 percent in June 2006 to become 5.24 percent in December 2006, the growth rate of 
domestic bank credit allocated to the domestic private non-financial sector increased from 1.1 percent in June 2006 to become 3.8 percent in December 2006.

In addition to above two variables, the data also indicates that other macroeconomic variables may also affect domestic bank credit in Indonesia. The following chart shows data for industrial production index (which in this study is used as a proxy for GDP for monthly frequency) and domestic bank credit bank credit. These two series tends to move in the same direction.



Figure 3. IP and Bank Credit

Source: Bank Indonesia and OECD Database.

The following charts shows data on the US\$ with Indonesia Rupiah exchange rate and bank credit growth. These two series also has a tendency to display a positive relationship.

Figure below shows data series for CPI and bank credit growth in Indonesia. The two series indicate that they move in opposite directions.

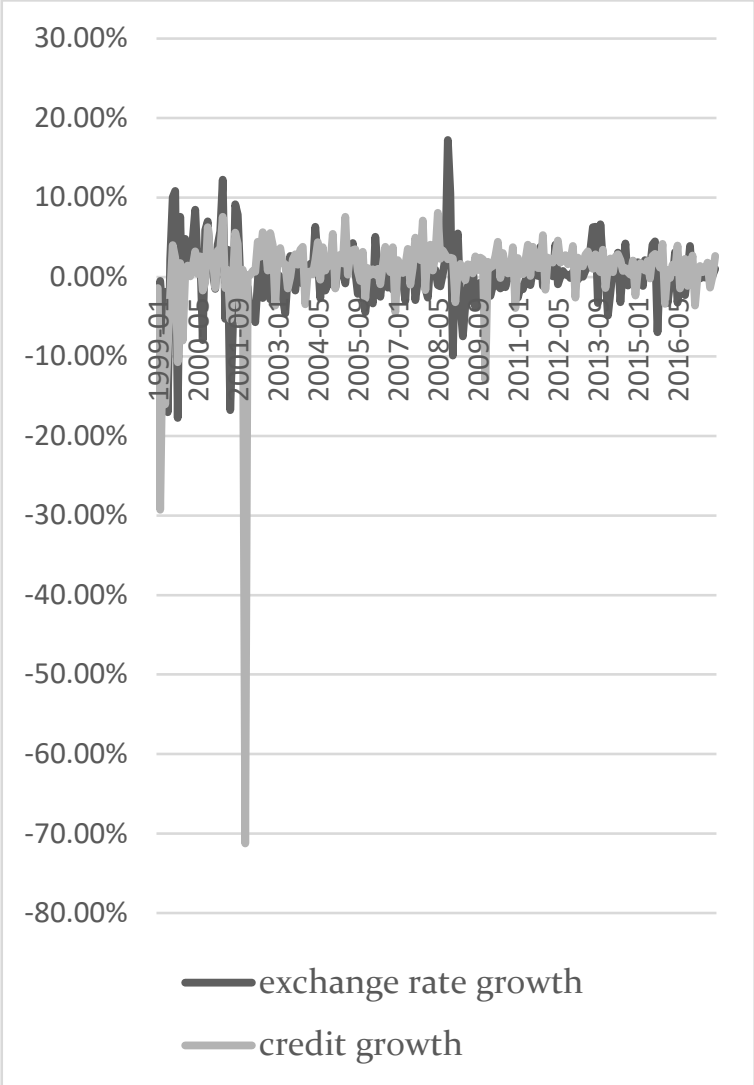

Figure 4. Exchange Rate and Bank Credit Source: Bank Indonesia

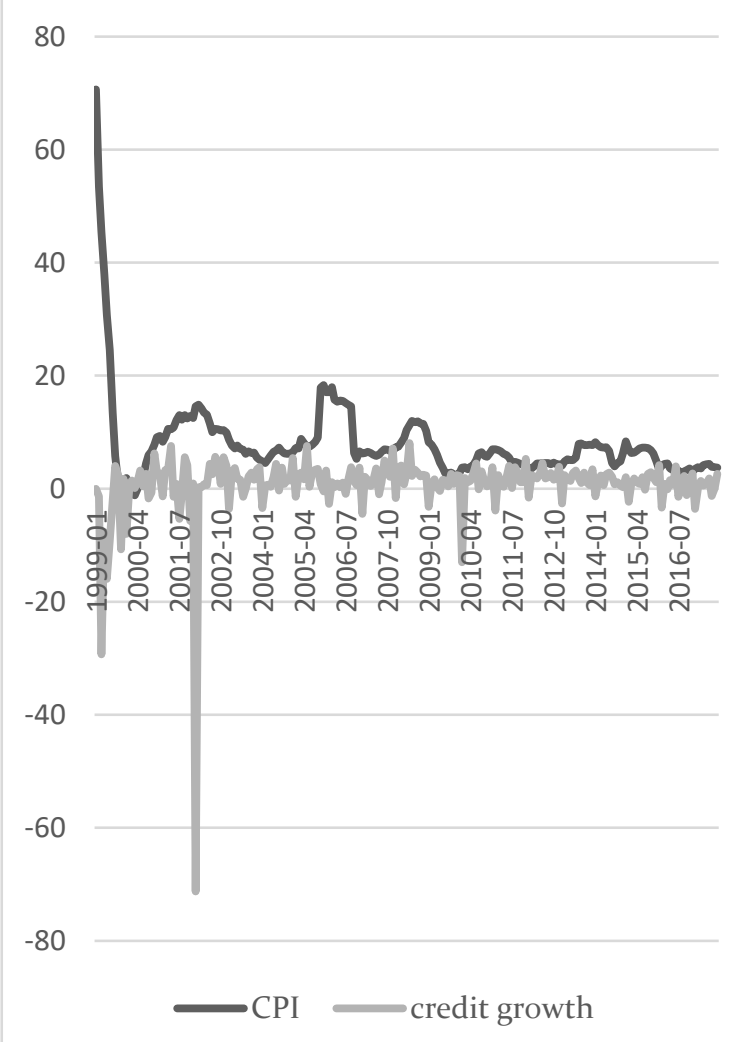

Figure 5. CPI and credit Source: Bank Indonesia 


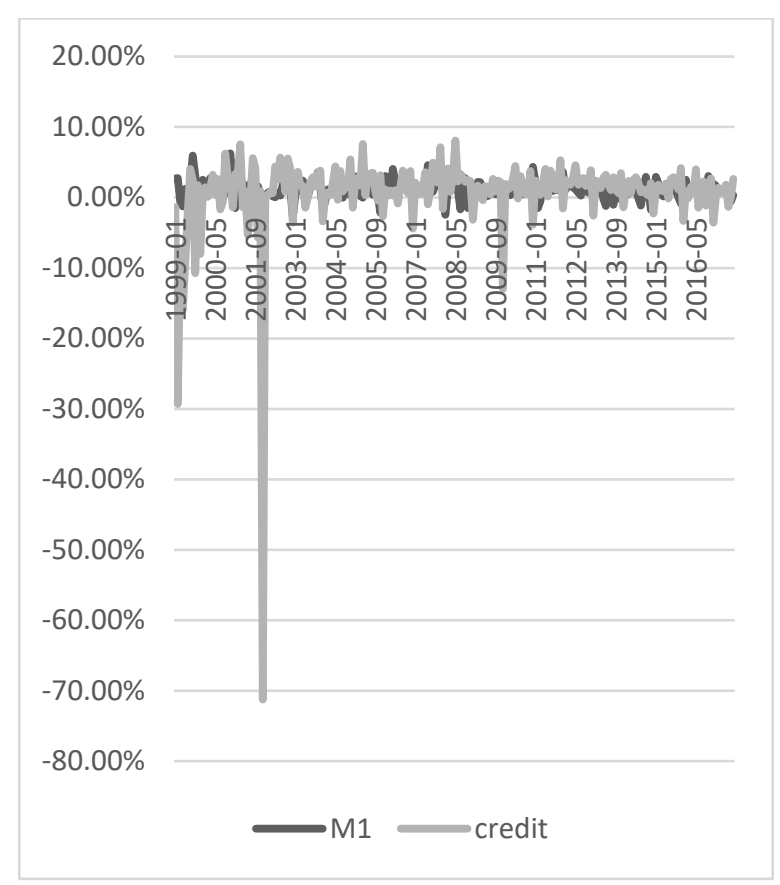

Figure 6. Mi and Credit

Source: Bank Indonesia

Unlike the CPI, the growth of monetary aggregate $\mathrm{M}$, displays close dynamic with that of domestic bank credit growth and the series tend to move in the same direction. This is shown in figure 6 above.

Although the data indicates some form of pattern of relationship between macroeconomic variables with domestic bank credit, however there yet to be a study which provides empirical evidence on such relationship for Indonesia in the literature. Although the data indicates some form of pattern of relationship between macroeconomic variables with domestic bank credit, however trends as shown in the figures above cannot ascertain the impact of foreign interest rates on bank credit in Indonesia. For this purpose, a formal empirical analysis is required.

Despite the importance of credit from the banking sector for the financing landscape of Indonesia, there does not exists a study which analyse empirically the effect of monetary policy and foreign interest rates on domestic bank credit in Indonesia. Thus the current study aims to fill the gap in literature by providing an empirical analysis on the effect of foreign interest rates and monetary policy on domestic bank credit for the private sector in Indonesia

The following section provides literature review on the mechanism on how monetary policy affects bank credit, and also how foreign interest rates affects domestic bank credit. The effect of monetary policy on bank credit are categorized into two arguments. The two arguments presented in this sections are the balance sheets channel and the bank lending channel. While the mechanism of the effect of foreign interest rates on domestic bank credit uses the argument of the risk taking channel of monetary policy transmission mechanism. The first argument presented in the literature review is the balance sheet channel.

The balance sheets channel monetary policy transmission mechanism argument was put forward by (Bernanke, Gertler, \& Gilchrist, 1999). This model has been applied and extended in numerous angles. An example of these extensions is Angelopoulou and Gibson (2009). This paper found evidence of the balance sheet channel of monetary policy transmission mechanism in The United Kingdom. In addition Chami and Cosimano (2010) found that the effect of monetary policy on bank credit with existence of the Basel Accord risk-based capital requirements, is evident and worked through the balance sheet channel. Aysun and Hepp (2011) found that balance sheet channel transmission mechanism of monetary policy is stronger when the assets of the banks' are securitized. Delli Gatti et al. (2010) shown that the balance sheet channel can operate with an element of networking 
of credit. While Dedola and Lombardo (2012) found that exposure of foreign countries through a balance sheet channel which are interconnected provided a strong source of propagation mechanism of producing asymmetric shocks across economies.

In sum the balance sheet channel argues that a monetary policy contraction would increase the domestic rate of interest. In turn the rate of interest rise causes a decrease the market value of balance sheet of firms. The motivation behind this outcome is due to negative relation concerning bond market value and its rate of return (Mishkin, 2013). Consequently, the rate of interest rise would reduce bonds market value and hence diminishes the firm's balance sheet's market value.

A second channel in which monetary policy can affect bank credit is the bank lending channel monetary policy transmission mechanism. The argument of this channel was proposed by (Bernanke \& Blinder, 1992). Just like the balance sheet channel, there are various applications and extensions of the bank lending channel. An example of application of the bank lending channel is Matousek and Sarantis (2009). This paper found empirical evidence of the bank lending channel monetary policy transmission mechanism in eight Central and Eastern European countries which are members of the European Union. This paper also found that the strength of the bank lending channel varies among countries and depends on the size and liquidity of the banks. While de Mello and Pisu (2010) found empirical evidence of the bank lending channel monetary policy transmission mechanism in Brazil. While Disyatat (2011), using a Dynamic Stochastic General Equilibrium model, found that the effect of the bank lending channel monetary policy transmission mechanism is weaker or stronger depending on the state of health of the banking sector. In addition this analysis found that the importance of the bank lending channel is enhanced with the greater reliance on market-based funding and in a well-developed financial system.

In sum, the discussion of the bank lending channel is the following. A monetary contraction raises domestic interest rates, which reduces bank's balance sheets values used for reserves. This would induce banks to decrease new and existing credit provision to firms. Ultimately this results in reduction of bank credit, but with a lag. In sum this arguments stipulates that a monetary contraction results in a fall in bank credit but with a lag.

The last exposition of this literature review is the argument on the effect of foreign interest rates on domestic bank credit. In discussing the impact of foreign interest rates on quantity of bank credit, I employ the argument of the Risk Taking Channel proposed by (Adrian \& Song Shin, 2010). There are numerous applications and extensions of this argument in the literature. Borio and Zhu (2012) found that alterations and innovations in the financial system and prudential rules had raised the significance of the risk taking channel of monetary policy transmission mechanism. This paper also argued that the increased in prominence of the risk taking channel has the possibility of increasing the likelihood of the occurrence of business cycle fluctuations which may have detrimental effects towards the economy. Angeloni, Faia and Lo Duca (2015) showed the existence of the risk taking channel of monetary policy transmission mechanism. This paper found that an expansionary 
monetary stance enhances the risk and the leverage of domestic banks. Furthermore, the monetary expansion resulted in banks taking higher risk, and the possibility of surges of the volatility of asset prices. While using confidential data of internal ratings of banks on businesses loans Dell'ariccia, Laeven and Suarez (2017) found empirical evidence of the risk taking channel of monetary policy transmission mechanism in the banking system of the United States. The found a negative relationship between short-term interest rates and the degree of risk taking (and thus the amount of bank credit).

In sum, the risk taking channel of monetary policy transmission mechanism argument is as follows. (Adrian \& Song Shin, 2010) in their argument used the concepts Net Interest Margin and term spread. Net Interest Margin (NIM) is total interest income on the bank's balance sheet asset side minus the interest expense on the liabilities side. It governs profitability of total bank lending, present value of bank's income and capital. While term spread is the determinant of profitability of credit to the private non-financial sector, on the margin added to bank's the balance sheet, which in turn affects future NIM.

The argument on how foreign interest rates affects bank credit by using the risk taking channel is as follows. Given that the banking system in a small open developing economy holds foreign assets in their balance sheet. Assume also that they take foreign borrowings. Suppose due to some external shock results in foreign interest rates to increase. Following the discussion of the Risk Taking Channel, if the increase causes the total interest income to fall short of total interest cost in bank's balance sheet. In turn this cause NIM to fall, which ultimately result in a fall of the size of domestic bank credit provision to the private sector. In sum the risk taking channel predicts that a rise in foreign interest rates results in a fall in domestic bank credit. As a note the risk taking argument of the impact of a rise in foreign interest on domestic bank credit is depends whether it increase causes the total interest income to fall short of total interest cost in bank's balance sheet, or on the other hand it causes total interest income to increase by more than the rise of total interest cost in bank's balance sheet. If the rise in foreign interest rates causes total interest income to increase by more than the rise of total interest cost in bank's balance sheet, this would instead result in increased bank credit.

\section{RESEARCH METHODS}

This paper employs the Structural Vector Autoregressive model (SVAR). The SVAR model consists of eight variables which can be specified in the following vector.

$$
\mathbf{Y}_{\mathrm{t}}^{\prime}=\left(\text { opw }_{i}, f f r_{i}, \text { ip }_{i}, c p i_{i}, m_{t_{t}}, \text { rdom }_{i}, \text { er }_{i}, c r_{t}\right)(\mathbf{1})
$$

The first three variables in the vector above are opw $w_{t}$ which denotes world oil prices, $f f r_{t}$ denotes the Federal Funds rate (which I use as to represent rates of interest of foreign) and $i p_{t}$ denotes industrial production correspondingly. The next three variables in the above vector are consumer price index $c p i_{t}$, base money $m_{1}$ and domestic short term interest rates rdom $_{t}$ respectively. While the remaining two variables in the aforementioned vector are the nominal exchange rate denoted as $e r_{t}$, and credit provision by banks to the nonfinancial private sector denoted as $\mathrm{cr}_{t}$ correspondingly. 
In general, the model in structural form with $p$ number of lags can be written as the following.

$$
C_{\mathrm{o}} Y_{t}=k+C_{1} Y_{t-1}+C_{2} Y_{t-2}+\ldots .+C_{p} Y_{t-p}+v_{t}
$$

Denoting $Y_{t}$ as an ( $\left.\mathrm{n} \times 1\right)$ vector, is $k$ a ( $\mathrm{n}$ $\mathrm{X} 1)$ vector of constants, $v_{t}$ is an ( $\left.\mathrm{n} \mathrm{X}_{1}\right)$ vector of structural shocks. The structural shocks $v_{t}$ are serially and mutually uncorrelated. The contemporaneous matrix $C_{o}$ is be defined as the following.

$$
C_{\mathrm{o}}=\left(\begin{array}{cccc}
1 & { }^{-} C_{12}^{(\mathrm{o})} & \ldots & -{ }^{(\mathrm{o})} \\
\vdots & \vdots & \cdots & \vdots \\
\vdots & \vdots & \cdots & \vdots \\
{ }^{-} C_{n 1}^{(\mathrm{o})} & { }^{-} C_{n 1}^{(\mathrm{o})} & \cdots & 1
\end{array}\right)
$$

Whereas the matrix $C_{s}$ is a matrix of dimension ( $\mathrm{n} \quad \mathrm{x} \quad \mathrm{n})$ which the row kand column $l$ element of the matrix is $C_{k l}^{(r)}$ for $r=$ $1,2, \ldots, \mathrm{p}$. Given the existence of the inverse matrix $C_{\mathrm{o}}^{-1}$, the above structural model can be modified by pre-multiplying equation (2) above to get the following result.

$$
\begin{aligned}
Y_{t}= & C_{\mathrm{o}}^{-1} k+C_{\mathrm{o}}^{-1} C_{1} Y_{t-1}+C_{\mathrm{o}}^{-1} C_{2} Y_{t-2}+\ldots \\
& +C_{\mathrm{o}}^{-1} C_{p} Y_{t-p}+C_{\mathrm{o}}^{-1} v_{t}
\end{aligned}
$$

Rewrite equation (4) into the following form.

$$
Y_{t}=d_{\mathrm{o}}+\varphi_{1} Y_{t-1}+\varphi_{2} Y_{t-2}+\ldots+\varphi_{p} Y_{t-p}+e_{t}(5)
$$

Where the above matrix/vectors are defined as the following.

$$
\begin{aligned}
& d_{\mathrm{o}}=C_{\mathrm{o}}^{-1} k \\
& \varphi_{j}=C_{\mathrm{o}}^{-1} C_{j} \text { for } \mathrm{j}=1,2, \ldots \mathrm{p} . \\
& e_{t}=C_{\mathrm{o}}^{-1} v_{t}
\end{aligned}
$$

Equation 4 is the structural dynamic model, while equation 5 is the structural model in reduced form and the vector $e_{t}$ are reduced form residuals. The relationship between the structural shocks and the reduced form residuals can be written in the following equation.

$$
v_{t}=C_{\mathrm{o}} e_{t}
$$

Equation 9 implies, identification of the structural shocks is dependent on the contemporaneous matrix $C_{\mathrm{o}}$.In identifying the structural shocks, I employ the strategy from literature (see (Barnett, Bhadury, \& Ghosh, 2016)) and extend it to include domestic credit. The strategy for identifying the shocks is presented in the following matrix.

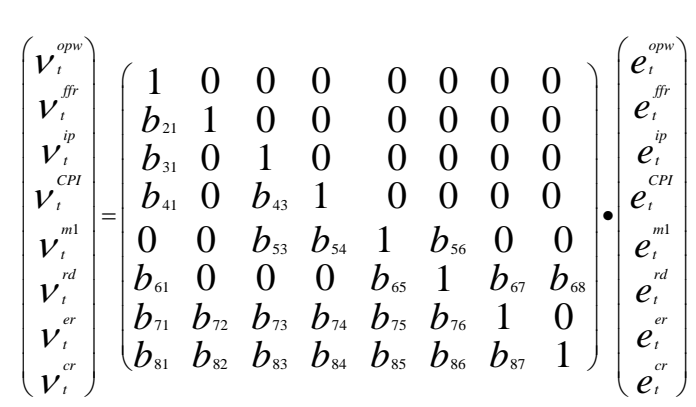

Using the Akaike Information Criterion (see (Doan, 2013)), 13 lags is found to appropriate for the above model. The data used in this study are obtained from Bank Indonesia and the OECD data base.

\section{RESULTS AND DISCUSSION}

In analysing the response of bank credit due to shocks to monetary policy and foreign interest I employ Impulse Response Analysis. In examining the Impulse Response Function I use the Bayesian Monte Carlo Integration approach in RATS statistical package. Using 90 percent confidence bands, this package draws 10,000 replications by using the Random Walk Metropolis Hastings method (see (Doan, 2013)). The results are presented in figures 7 and 8.

The Impulse Response Function analysis for a one percent rise in foreign interest rates is depicted in figure 7 below. The discussion 
on the impact of the one percent foreign interest rate shocks on various macroeconomic variables are presented in the following paragraph.

From figure 7 below it is shown that the one percent increase in the Federal Funds Rate resulted in in a decrease in the world price of crude oil. This is a reasonable result because the economy of the United States is a large economy relative to the world. It is well known from standard macroeconomic theory that an increase in the interest rates of the domestic economy, in this case the interest rate of The United States, resulted in a contraction of the economy of the United States. The contraction of the economy of the United States, resulted in a decrease in energy demand, in particular for crude oil. Due to the significance of the economy of the United States relative to the world economy, this implies crude oil demand by the United States is a significant fraction of total crude oil demand for the world. Thus a decline of crude oil demand from the United States due to economic contraction caused by the Federal Fund rate hike resulted in a significant fall of global crude oil demand. In the end this results in a fall of world crude oil prices as shown in figure 7 .

From figur below it is shown that the one percent increase in the Federal Funds rate, resulted in a fall in global oil prices starting from the third month post of the foreign interest rate shocks. The fall of global crude oil prices reaches its trough after seventh months of the Federal Funds rate negative shock, where in the sixth month world crude oil fell by approximately 2.5 percent. This fall in world crude oil prices continued to fall up to the seventh month post month post of the foreign interest rate shocks.
Interestingly, the increase of foreign interest, resulted in Gross Domestic Product of Indonesia. From figure shows that, post 8 months of the Federal Funds rate negative shock, Indonesia GDP increased by approximately 0.5 percent. The reason for this result is that, noting that the Federal Funds rate negative shock has resulted in the decrease of Global crude oil prices. This implies that global energy prices and energy prices faced by Indonesia fell. From standard macroeconomic theory, the fall in energy prices would ultimately result in an increase in Gross Domestic Product. The negative shock of the Federal Funds rate does not have significant effect on domestic inflation. From figure 7 it is shown that the one percent Federal Funds rate negative shock results in a decrease in the growth of domestic Consumer Price Index of Indonesia by 0.2 percent. However, the decrease in domestic inflation due to the shock of foreign rates of interest is not significant.Similarly, the negative foreign rates of interest shock also does not have a significant impact on money supply. From figure 7 it is shown that the one percent Federal Funds rate negative shock resulted an increase in base money by around 0.25 percent. However just like for inflation, the effect the one percent Federal Funds rate negative shock does not have a statistically significant impact on the money base. In addition, the negative shock of foreign rates of interest has no significant impact domestic interest rates.

With the increase of the Federal Funds rate by one percent figure 7 shows that domestic interest rates fell by around $\mathbf{0 . 2}$ percent. On the contrary, the negative foreign rates of shock did not have a statistically significant impact domestic interest rates. 
Unlike inflation, money supply and domestic interest rates, a shock of foreign rates of interest has a significant depreciating impact on the nominal exchange rate. From figure 7 it is shown that the increase of the Federal Funds rate by one percent resulted in a depreciation of the nominal exchange rate between the Rupiah and the US dollar. After six months of the negative foreign interest rates shock, the nominal exchange rate depreciated by 1 percent. The depreciation of the nominal exchange rate due to the negative Federal Funds rate shock continued up to 7 months post the shock. As a note, unlike the case for inflation, money supply and domestic interest rates, the negative foreign rates of interest results in a depreciation of the nominal exchange which is statistically significant. The reason for this result follows from standard open macroeconomic theory. Open macroeconomic theory posits that an increase in foreign interest rates, cateris paribus, results in interest rates and returns differential between foreign assets with domestic assets increases such that foreign assets becomes more attractive to purchase and hold than domestic assets. The wedge between foreign and domestic assets created by the foreign interest rates shocks resulted increased capital outflows. The increase in capital outflow out of Indonesia increases exchange rates pressure for the nominal interest rates to depreciate.

Focusing on the impact of foreign interest rates on the volume of domestic bank credit allocated to the domestic private non-financial sector, the discussion is as follows. Initially the one percent rise in foreign interest rates shock resulted in a two percent decrease of the private non-financial sectors' provision of domestic bank credit in Indonesia in the seventh month. This result is consistent with the results found by
(Bruno \& Shin, 2015). In that paper it is found that a contraction of the monetary policy stance of large foreign country resulted in a decrease in the flows foreign capital channelled by international banks' to domestic banks of the developing country. The decrease in domestic credit due to the negative foreign rates of interest occurs 7 months post of the shock. The reduction of the foreign capital inflow in turn would have an impact of reducing funds available for domestic banks of the developing country that can be used for lending. Ultimately the monetary contraction of the central bank of the large foreign country would decrease the amount of domestic credit in the developing country.
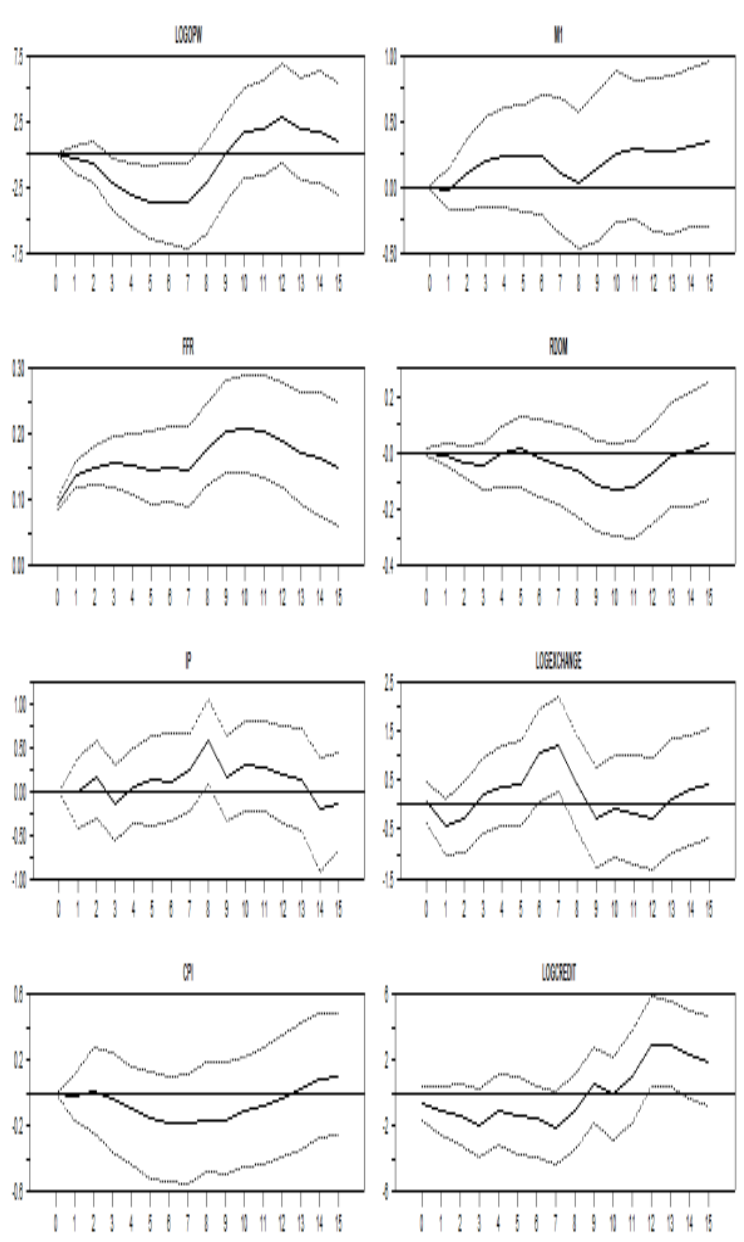

Figure 1. Response to foreign interest rate shocks for Indonesia Source: Research output 
As a note (Bruno \& Shin, 2015) had shown that this mechanism on how foreign interest rates affects domestic bank credit, explains partially the flow of capital from developed countries to developing countries in the 1990-s. Furthermore result finding of the decline of domestic bank credit due to the rise of the foreign interest rate is also in line with result found by (Zanforlin, 2011). This paper found that an increase in foreign interest rates results in an increase in foreign funding cost. In turn the increase in foreign funding cost results in a fall of the source of funding for domestic banks which can be channelled to domestic borrowers. In the end the rise in foreign interest rate would result in a fall of domestic bank credit.

Figure 7 also shows that subsequently however the result of the impulse response graph shows that bank credit increased after 12 months. The reason for this results follows from the Risk taking channel argument. Following the argument of Adrian and Shin (2011). The argument on how foreign interest rates affects bank credit using the risk taking channel is as follows. Given that the banking system in a small open developing economy holds foreign assets in their balance sheet. Assume also that they take foreign borrowing. Suppose due to some external shock results in foreign interest rates to increase. Following the discussion of the Risk Taking Channel, if the rise in foreign interest rates causes total interest income to increase by more than the rise of total interest cost in bank's balance sheet, this cause the Nett Interest Margin of supplying new credit by the bank to rise. Ultimately the rise in foreign interest rate would result in a rise of the size of domestic bank credit provision to the private sector. Given that firm $\mathrm{s}$ are financially constrained, this results in an increase in domestic bank credit.
In addition, given that firms have sufficient time to adjust their balance sheet, I argue that this result is partially also be due to banks and firms having sufficient time to adjust and substitute away from the more costly foreign credit to domestic bank credit. The combination of the increased supply of domestic bank credit by domestic banks plus the increase in demand of domestic credit by domestic firm resulted in the increase of domestic bank credit in the economy.

For the Impulse Response Analysis of monetary policy shocks, a monetary tightening which resulted a one percent rise of Indonesian interest rate. From figure 8 below it is shown that the one percent increase in the policy rate of Bank Indonesia resulted in in a decrease in the world price of crude oil up to 5 percent since five months post of the monetary policy contraction shock. However from figure 7 it is shown that the fall in world crude oil price due to the change in policy stance of Bank Indonesia was not statistically significant. This implies that monetary policy stance of bank Indonesia has little or no influence on the global price of crude oil. This is a reasonable result because Indonesia is a small demander of crude oil relative to the world demand for oil. This stands to reason that a monetary contraction or monetary expansion by Bank Indonesia has very little or no impact towards the global price of crude oil.

Monetary policy shocks has no significant effect on foreign rates of interest. From figure 8 it is shown that a percent tightening of the policy rate of Bank Indonesia resulted in a rise of the Federal Funds Rate by up to 0.05 percent. The rise in the Federal Funds rate due to the change in monetary policy stance of Bank Indonesia 
started since the $8^{\text {th }}$ month post of the monetary policy shock. However, similar to the results for world crude oil prices, figure 8 shows that the response of the Federal funds rate due to the monetary policy shock is not statistically significant. The reason for the insignificant impact of monetary policy shocks of Banks Indonesia on foreign rates of interest (in this case is the Federal Funds rate) is because Indonesia is an open economy which is relative small compared to the economy of the United States and the world, Because Indonesia is relative small relative to the economy of The United Stated thus a changes in the monetary stance of Bank Indonesia does not have any influence towards the global economy and the economy of The United Sates.
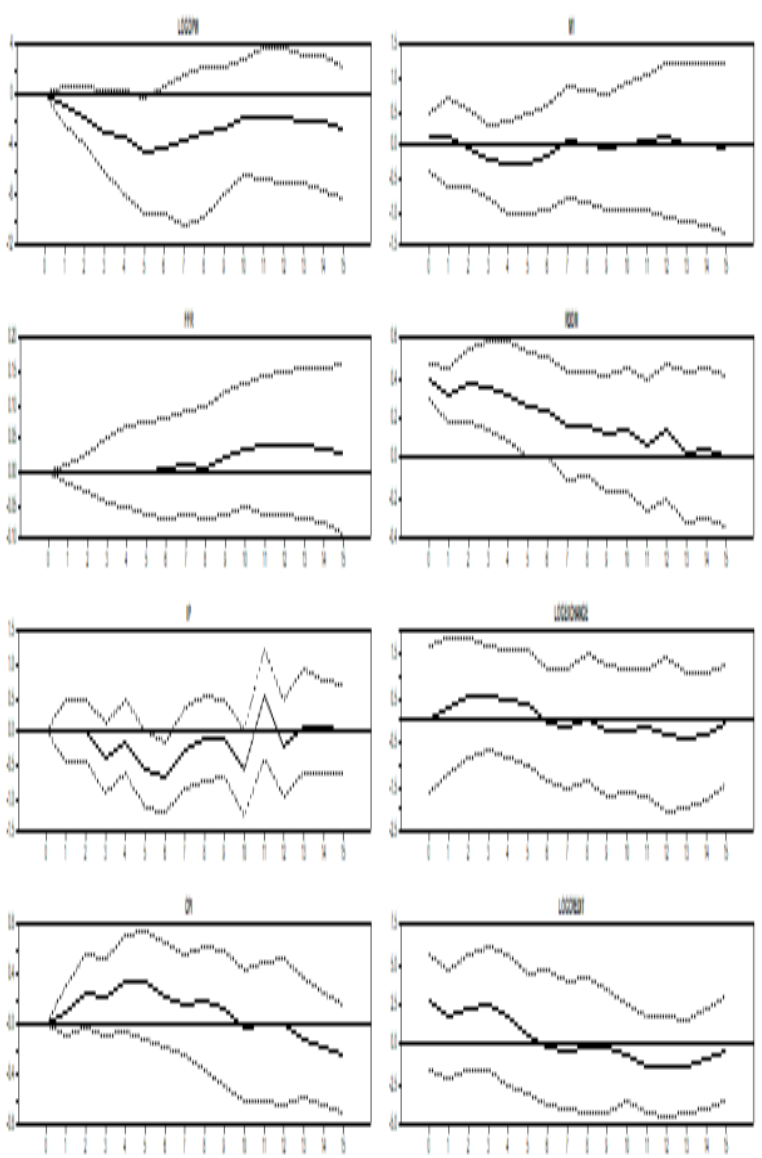

Figure 8. Response to monetary policy shocks for Indonesia

Source: Research output
Unlike world crude oil prices and the Federal Funds rate, a one percent contraction of the monetary policy shock of bank Indonesia results in a significant decrease of the Indonesia Gross Domestic Product. Figure 8 shows that a one percent contraction of the policy rate of Bank Indonesia resulted in a fall in Gross Domestic Product of Indonesia by 0.5 percent. This fall in GDP due to the negative monetary policy shock occurred at the seventh month post of the monetary policy shock. From figure 8 it is shown that the fall in Gross Domestic product due to the negative shock to the monetary policy stance of Bank Indonesia is statistically significant.

Monetary policy shock has marginally affect domestic inflation in Indonesia. From figure 8 above it can be seen that a negative shock to the monetary policy rate of Bank Indonesia, initially causes inflation to rise about 0.2 percent after 2 months of the monetary policy shock. As a note, the rise in inflation due to the one percent rise in Bank Indonesia's policy rate is marginally statistically significant. Subsequently, inflation in Indonesia fell by approximately 0.3 percent. The subsequent fall of inflation occurred 10 months post to the negative monetary policy shock. However the fall in inflation due to the monetary policy shock is not statistically significant. The results that a negative monetary policy shock of bank Indonesia results in an increase in inflation, followed by subsequent fall in inflation is consistent to the results found by (Bernanke \& Blinder, 1992). This paper found that the impact of a monetary contraction is delayed response in which it is preceded by a rise inflation which subsequently followed by a fall in inflation.

Contrary to the effect of a negative monetary policy shock on inflation, the effect 
the shock on money supply is not significant. From figure 8 it is shown that the one percent rise in the policy rate of Bank Indonesia barely have any effect on Mi. In addition the impact of monetary policy shock on $\mathrm{m} 1$ is not statistically significant.

Similarly to money supply, world oil price and The Federal Funds rate, monetary policy shocks has no significant effect on the nominal exchange rate. From figure 8 above it is shown that the rise in Bank Indonesia' $s$ policy rates results initially results in a depreciation of the nominal exchange in the fourth month post of the monetary policy shock. Subsequently the impact of a negative monetary policy shock results in an appreciation of the nominal exchange at the 13 months post of the Federal Funds negative shock. However the impact of the exchange rate due to the negative monetary policy shock is not statistically significant. Although not statistically significant, the monetary policy shock resulted in initial depreciation of the nominal exchange rate, which is followed by a subsequent appreciation of the nominal exchange rate is in line with the results in (Bernanke \& Blinder, 1992).

Focusing in the impact of a one percent negative monetary policy shock on domestic bank credit allocated to the domestic private non-financial sector, Although not statistically significant, the impulse response graphs indicates that the rise in Indonesian interest rate causes the sum of bank credit in the country to decline, but with a lag. This outcome in line with the conclusion found by bank lending channel monetary policy transmission mechanism put forward by (Bernanke \& Blinder, 1992) and verified by Vera (2012), although this paper showed that the impact of the bank credit monetary policy transmission mechanism has weakened as compared to the $1990 \mathrm{os}$

The insignificant effect of monetary policy on domestic bank credit in Indonesia as shown from the Impulse Response Function graphs indicates that monetary policy is less appropriate tool in manage the growth of bank credit in Indonesia to safeguard the health and soundness of the Indonesia financial system.

In addition to Impulse Response Analysis, this study also employs analyses the Forecast Variance Error Decomposition. The Forecast Variance Error Decomposition measures the proportion of variation of an endogenous variable in the model due to various shocks included in the model. In sum, the magnitude of the Forecast Variance Error Decompositions provide measurement of the strength of the influence of each shocks on the corresponding endogenous variable in the model (Barnett et al., 2016).

The information for the Forecast Variance Error Decomposition analysis was obtained from the research output and is presented in table 1 below. The first to notice of the results is that the percentage variation of monetary policy shocks on domestic bank credit is small. On impact, the percentage variation of domestic bank credit due to the monetary policy shock is less than four percent. The magnitude of variation of monetary shocks on domestic bank credit remains below four percent up 12 months. This results indicates that monetary policy is not very potent instrument in influencing domestic bank credit. This result is in line with the finding of Vera (2012), in which this paper found that the strength of the bank lending channel had waned in the United States. Considering the results obtained from the estimation, a further question that can be posed is why has the monetary policy on 
domestic bank credit in Indonesia had weakened? One answer that can offered for this question, is that it is due to financial development and financial innovations. Altunbas, Gambacorta and Marques-Ibanez (2010) found that financial innovations resulted in weaker influence of monetary policy on bank credit. As found by this paper, advancements in financial innovations (such as credit derivatives and securitizations of assets) enables banks to give out new loans and sell them in the financial market thus obtaining additional liquidity and relaxing constraints in the capital requirement in generating new loans.

In addition table 1 shows foreign interest rates can influence on domestic bank credit, and its influence can be more important than monetary policy. As shown in table 1 below, the variation of bank credit to non-financial private sectors vis-à-vis monetary policy dominates foreign interest rates on the first month. Yet after 6 months, the variation of the Federal Funds rate surpass that of monetary policy. The reason for this result is that it may be due to the open capital account of the Indonesian financial system, and the result of increased globalization which made Indonesia to be more integrated the global financial market. This argument is in line with Claessens et al. (2010). In relation to this argument, Bruno and Shin, (2015) had shown that the impact of a change in monetary policy stance of the United States is transmitted globally and influences the flow of capital in other nations,

The last result above suggests that in addition to monetary policy, foreign interest rates also has an important influence on banks' credit in Indonesia. This is a novel finding and contribution of the paper to the literature of economics; both monetary policy and foreign interest rates influences bank credit in Indonesia. In addition the results indicates that monetary policy stance of Bank Indonesia influences bank credit only up to 12 months. After 12 months, foreign interest rates dominates. In addition from the impulse response functions it is shown that the impact of the change of the policy stance of Bank Indonesia does not significantly affect bank credit in Indonesia. On the other hand the Impulse Response Analysis shows that foreign interest rates have a significant effect on bank credit. These results underscores that monetary policy is less effective as a tool to be used in managing the growth of bank credit. This result is in line with the finding by (Vera, 2012). Therefore monetary policy is not effective for nurturing the stability of Indonesia's financial system. To oversee the growth of bank credit, macroprudential policies should instead be used in the effort to maintain the soundness of Indonesia's financial landscape. In addition authorities in charge of macroprudential policies should take into account the effect of foreign interest rates and also financial innovation in formulating and implementing the policies.

Table 1. Forecast Variance Error Decomposition

\begin{tabular}{cccc}
\hline Months & standard error & rf & rdom \\
\hline 1 & 5.867 & 1.208 & 3.859 \\
3 & 9.269 & 2.062 & 2.904 \\
4 & 10.607 & 3.347 & 3.695 \\
6 & 12.059 & 3.188 & 3.057 \\
12 & 14.39 & 5.629 & 3.238 \\
24 & 17.281 & 10.976 & 4.386 \\
48 & 22.687 & 7.014 & 5.618 \\
72 & 26.86 & 5.688 & 6.575 \\
\hline
\end{tabular}

Source: Research output 


\section{CONCLUSION}

Employing a structural VAR model on Indonesia data, this paper found that domestic credit provided by banks in Indonesia is affected by both interest rates from abroad and monetary policy. Initially both monetary policy and foreign interest rates influences domestic bank credit, but after 12 months foreign interest rates dominated monetary policy. Furthermore from the IRF, a rise in foreign interest rates initially results in a fall in bank credit due to the risk taking channel argument. But as banks and firms had time to substitute away from the foreign credit which have become more costly to domestic bank credit, foreign interest rate hike results in a rise in domestic bank credit. However monetary policy has no significant effect on domestic bank credit. These novel findings of the paper underlines that monetary policy is less effective as a tool in managing credit growth. Other policies such as macroprudential polices should instead be used in the effort to guard the stability of Indonesia's financial system.

Furthermore, in formulating and conducting macroprudential policies, Bank Indonesia should take into account the effect of foreign interest rates on bank credit in Indonesia. The current analysis focuses on the effect of foreign interest rates and monetary policy in a particular country. For future work it would be fruitful to conduct the analysis on other countries or group of countries.

\section{REFERENCES}

Adrian, T., \& Song Shin, H. (2010). Financial intermediaries and monetary economics. Handbook of Monetary Economics (Vol. 3). https://doi.org/ 10.1016/B978-0-444-53238-1.00012-0

Angelopoulou, E., \& Gibson, H. D. (2009). The balance sheet channel of monetary policy transmission: Evidence from the United Kingdom. Economica,
76(304), 675-703. https://doi.org/10.1111/j.14680335.2008.00710.x

Aysun, U., \& Hepp, R. (2011). Securitization and the balance sheet channel of monetary transmission. Journal of Banking and Finance, 35(8), 2111-2122. https://doi.org/10.1016/j.jbankfin.2011.01.011

Barnett, W. A., Bhadury, S. S., \& Ghosh, T. (2016). An SVAR Approach to Evaluation of Monetary Policy in India: Solution to the Exchange Rate Puzzles in an Open Economy. Open Economies Review, 27(5), 871-893. https://doi.org/10.1007/s11079-016-9403-2

Bernanke, B. S., \& Blinder, A. S. (1992). The federal funds rate and the channels of monetary transmission. American Economic Review, 82(4), 901-921. https://doi.org/10.2307/2117350

Bernanke, B. S., Gertler, M., \& Gilchrist, S. (1999). Chapter 21 The financial accelerator in a quantitative business cycle framework. Handbook of Macroeconomics. https://doi.org/10.1016/S15740048(99)10034-X

Bruno, V., \& Shin, H. S. (2015). Capital flows and the risk-taking channel of monetary policy. Journal of Monetary Economics, 71, 119-132. https://doi.org/ 10.1016/j.jmoneco.2014.11.011

Chami, R., \& Cosimano, T. F. (2010). Monetary policy with a touch of Basel. Journal of Economics and Business, 62(3), 161-175. https://doi.org/10.1016/ j.jeconbus.2009.12.001

de Mello, L., \& Pisu, M. (2010). The bank lending channel of monetary transmission in Brazil: A VECM approach. Quarterly Review of Economics and Finance, 50(1), 50-60. https://doi.org/10.1016/j.qref.2009.09.006

Dedola, L., \& Lombardo, G. (2012). Financial frictions, financial integration and the international propagation of shocks. Economic Policy, 27(70), 319-359. https://doi.org/10.1111/j.14680327.2012.00286.x

Dell'ariccia, G., Laeven, L., \& Suarez, G. A. (2017). Bank Leverage and Monetary Policy's Risk-Taking Channel: Evidence from the United States. Journal of Finance, 72(2), 613-654. https://doi.org/ 10.1111/jofi.12467.

Delli Gatti, D., Gallegati, M., Greenwald, B., Russo, A., \& Stiglitz, J. E. (2010). The financial accelerator in an evolving credit network. Journal of Economic Dynamics and Control, 34(9), 1627-1650. https://doi.org/10.1016/j.jedc.2010.06.019

Disyatat, P. (2011). The bank lending channel revisited. Journal of Money, Credit and Banking, 43(4), 711734. https://doi.org/10.1111/j.1538-4616.2011.00394.x

Doan, T. (2013). RATS manual: version 8.3. Evanston: Estima.

Jiménez, G., Ongena, S., Peydró, J.-L., \& Saurina, J. (2014). Hazardous Times for Monetary Policy: What do 23 Million Loans Say About the Impact of Monetary Policy on Credit Risk-Taking? Econometrica, 82(2), 463-505. https://doi.org/ 
10.3982/ECTA10104

Matousek, R., \& Sarantis, N. (2009). The bank lending channel and monetary transmission in Central and Eastern European countries. Journal of Comparative Economics, 37(2), 321-334. https://doi.org/10.1016/j.jce.2008.09.0o8

Mishkin, F. S. (2013). The Economics of Money, Banking, and Financial markets /. Pearson Publications
Company.

https://doi.org/10.1017/CBO9781107415324.004

Vera, D. (2012). How responsive are banks to monetary policy? Applied Economics, 44(18), 2335-2346. https://doi.org/10.108o/ooo36846.2011.564143

Zanforlin, L. (2011). Domestic Lending when Financial Markets are Integrated: Is it all for Real. Applied Economics Letters, 18. 


\section{APPENDIX}

Table A1: Credit of Banking Sector to Total Financing in Developing Countries

\begin{tabular}{lccr}
\hline \multirow{2}{*}{ Country } & \multicolumn{3}{c}{ Year/Quarter } \\
\cline { 2 - 4 } & 2016 & Q1 17 & Q2 17 \\
\hline Argentina & $75 \%$ & $75 \%$ & $75 \%$ \\
Brazil & $94 \%$ & $94 \%$ & $94 \%$ \\
China & $75 \%$ & $75 \%$ & $75 \%$ \\
Malaysia & $97 \%$ & $97 \%$ & $96 \%$ \\
Mexico & $44 \%$ & $45 \%$ & $46 \%$ \\
Hungary & $36 \%$ & $36 \%$ & $37 \%$ \\
India & $94 \%$ & $95 \%$ & $95 \%$ \\
Indonesia & $\mathbf{8 8} \%$ & $\mathbf{8 9} \%$ & $\mathbf{8 8} \%$ \\
Greece & $86 \%$ & $86 \%$ & $86 \%$ \\
Thailand & $96 \%$ & $97 \%$ & $97 \%$ \\
Turkey & $72 \%$ & $73 \%$ & $74 \%$ \\
Poland & $63 \%$ & $63 \%$ & $64 \%$ \\
Saudi Arabia & $92 \%$ & $91 \%$ & $91 \%$ \\
South Africa & $91 \%$ & $90 \%$ & $90 \%$ \\
\hline average for & & & \\
developing & $79 \%$ & $79 \%$ & $79 \%$ \\
countries & & & \\
\hline
\end{tabular}

Source: Bank for international settlement
Table A2: Credit of Banking Sector to Total Financing in Developed Countries

\begin{tabular}{lccr}
\hline \multirow{2}{*}{ Country } & \multicolumn{3}{c}{ Year/Quarter } \\
\cline { 2 - 4 } United Kingdom & 2016 & Q1 17 & Q2 17 \\
\hline United States & $53 \%$ & $53 \%$ & $54 \%$ \\
Canada & $35 \%$ & $34 \%$ & $34 \%$ \\
Australia & $52 \%$ & $52 \%$ & $51 \%$ \\
Austria & $71 \%$ & $71 \%$ & $71 \%$ \\
Belgium & $59 \%$ & $58 \%$ & $59 \%$ \\
Czech Republic & $29 \%$ & $29 \%$ & $29 \%$ \\
Denmark & $58 \%$ & $58 \%$ & $58 \%$ \\
Finland & $77 \%$ & $78 \%$ & $78 \%$ \\
France & $53 \%$ & $53 \%$ & $52 \%$ \\
Germany & $50 \%$ & $50 \%$ & $50 \%$ \\
Italy & $72 \%$ & $71 \%$ & $71 \%$ \\
Japan & $72 \%$ & $72 \%$ & $72 \%$ \\
Korea & $68 \%$ & $69 \%$ & $69 \%$ \\
Netherlands & $68 \%$ & $69 \%$ & $69 \%$ \\
Norway & $48 \%$ & $48 \%$ & $48 \%$ \\
Spain & $32 \%$ & $32 \%$ & $32 \%$ \\
Sweden & $65 \%$ & $64 \%$ & $64 \%$ \\
Switzerland & $56 \%$ & $56 \%$ & $57 \%$ \\
Luxembourg & $79 \%$ & $79 \%$ & $79 \%$ \\
Ireland & $24 \%$ & $24 \%$ & $25 \%$ \\
Portugal & $16 \%$ & $17 \%$ & $18 \%$ \\
Russia & $60 \%$ & $59 \%$ & $59 \%$ \\
\hline average for & $76 \%$ & $76 \%$ & $76 \%$ \\
developed countries & $55 \%$ & $55 \%$ & $55 \%$ \\
\hline
\end{tabular}

